\title{
The synergy between government institutions in clean water preparedness for earthquake and tsunami disaster management in Banda Aceh City
}

\author{
M. Arifin ${ }^{1 *}, M$. Dirhamsyah ${ }^{2}$, and Nizamuddin ${ }^{3}$ \\ ${ }^{1}$ Departement of Disaster Science, Universitas Syiah Kuala, Banda Aceh, 23111, Indonesia \\ ${ }^{2}$ Departement of Mechanical Engineering, Faculty of Engineering, Universitas Syiah Kuala, Banda Aceh City 23111, Indonesia \\ ${ }^{3}$ Departement of Information Science, Faculty of Math and Science, Universitas Syiah Kuala, Banda Aceh City 23111, Indonesia
}

\begin{abstract}
Synergy is coordination and cooperation between groups of people in order to achieve an efficient goal. An example of a synergy is the synergy between government agencies to improve access to clean water in relation to disaster management. This study aims to describe the synergy between Indonesia's government agencies to improve access to clean water in relation to disaster management, determine the factors that affect the synergy, and recommend a synergy model. The study was conducted through a qualitative approach. Data were collected through in-depth interview with the heads of government agencies that had a duty to improve access to clean water, observation, and literature review. The data analysis technique was triangulation technique. The results of this study was that the synergy between the government agencies had not run well due to several inhibiting factors that were inefficient planning, overlapping work division, and no evaluation.
\end{abstract}

\section{Introduction}

There are so many catastrophic events that occur in Indonesia each year, and the number is increasing in the last few years. The number of catastrophic events in 2016, 2017, 2018 was 2,306, 2,391 and 2,572 respectively. From 2007 to 2018, earthquakes and tsunamis are two disasters that caused the highest number of casualties [1]. Natural disasters such as floods, volcanic eruptions, earthquakes, and tsunamis cause damage to the communication system, electricity supply, water supply, and in this crisis situation it is difficult to provide emergency response services [2].

Disasters can cause damage to the clean water distribution network system affecting the supply of clean water for millions of people. Like the earthquake that occurred in Northridge California in 1994 which resulted in 500,000 people losing clean water services [3]. For example, the earthquake that occurred in Northridge California in 1994 caused 500,000 people losing access to clean water. The earthquake also caused a huge fire due to the failure of clean water distribution by the fire department [4].

On March 11, 2011 at 2:46 p.m. local time, Japan was rocked by an earthquake with a magnitude of 9.0 on the Richter Scale and caused a tsunami on the East coast of Japan, which disrupted water supply for 2,300,000 households from Tohoku to Kanto due to damage to the clean water distribution network [5]. Meanwhile, the earthquake that occurred on April 14, 2016 in the vicinity of Kumamoto City with a magnitude of 6.4 on the Richter Scale caused 85,000 households to not get clean water due to the cessation of clean water distribution due to 69 of the 96 water sources in Kumamoto City experiencing turbidity that cannot be controlled received [6].
The tsunami in Banda Aceh in 2004 caused almost all river water to be processed before used, including the distribution pipes and well water in Lampaseh area. Moreover, it was found a high population of Coliform bacteria in the Krueng Raya Muara River as many as 3100 colonies / $100 \mathrm{ml}$. Only one of the two water treatment plants in Banda Aceh is still operating, about $75 \%$ of the distribution pipe network is damaged, and river water is also damaged. Also states in general the negative impacts of the earthquake and tsunami disaster on water infrastructures were that (1) there was damage to the intake towers, the water treatment plants, and distribution pipes, (2) the damage occured in areas near the shoreline, (3) the level of damage was up to $90 \%$, and (4) there was a problem in operational costs [7].

After the tsunami in Banda Aceh City occurred, the people there had difficulty accessing clean water. Some people in Gano Village, Syiah Kuala District, Banda Aceh City buy bottled drinking water/gallon water which is expensive, the cost is about $20 \%$ or $25 \%$ of their income, the water is used for bathing and washing [8]. The disaster caused power failures so that the tap did not turn on. Some people had access to well water, but it was very limited to 3 or 5 households because the wells were located in coastal areas. To use the wells, it was not free. The owner charged a price [8]. More than $60 \%$ of Banda Aceh City was destroyed. Some parts of the land disappeared, and the water infrastructures water were damaged so that only $20 \%$ of clean water was available after the tsunami. Groundwater that was contaminated by sea water was a big problem because it damaged the infrastructure of the Regional Drinking Water Company of Banda Aceh City[9].

In Lombok on August 52018 at 19.46 local time measuring 6.9 on the Richter Scale an earthquake occurred where the epicenter was $27 \mathrm{~km}$ northeast of

* Corresponding author: arifin90@mhs.unsyiah.ac.id 
North Lombok with a depth of $10 \mathrm{~km}$ [10]. According to the National Disaster Management Agency, the earthquake caused 506 people to die, 1,406 people injured, and 430,946 people to relocate. It also caused damage to the infrastructures, including water infrastructures [5].

Similar to the earthquake and tsunami that occurred in Palu, the earthquake also caused the people difficulty accessing clean water. Based on the interview with Darwis who was a UNICEF Indonesia representative in Palu and worked to improve access to Water, Sanitation, and Hygiene (WASH) on February 9, 2019, at 16.00 Western Indonesian Time (WIB), the clean water supply was very limited. In places of refuge, there was no clean water managed by the Regional Drinking Water Company and the boreholes owned by the society were damaged. Most residents whose houses were affected by the disaster in Palu City would choose to stay in their relatives' houses if the houses were safer because in the places of refuge the facilities were inadequate such as lack of access to clean water and a limited number of public toilets [11]. The earthquake that occurred in Palu measuring 7,5 on the Richter scale caused the 270meter-long water pipes meters from the total length of 28,079 that brought water to Tanamodindi Village to break and leak. It caused the society of Tanamodindi Village to get difficulty accessing clean water [12].

The earthquake in Lombok in 2019 also caused damage to the irrigation networks by $45 \%$ or 97 units, roads by $28 \%$ or 61 units, drinking water supply networks and wastewater treatment installations by $15 \%$ or 32 units, and the damage caused the society in Lombok get difficulty to access clean water [13]. Banda Aceh is a disaster-prone region especially earthquakes and tsunamis because Banda Aceh is bordered by Samudra Hindia where the Eurasian plate and the IndoAustralian plate meet. Banda Aceh is also prone to submarine earthquakes and inland earthquakes because there is the Great Sumatran Fault adjacent to Banda Aceh City [14].

The government of Banda Aceh City has an important role in disaster management. In accordance with the mandate of the Constitution Number 24 of 2007 concerning Disaster Management, the government of Banda Aceh City needs to mitigate disasters so that obstacles or problems that occur such as in 2004 can be overcome. Disaster preparedness is needed because the tsunami occurred in Aceh has a recurrence period that can occur once every 600 years [15]. Based on the prediction of the researchers from the Tsunami Disaster Mitigation Research Center (TDMRC), there will be an earthquake measuring 7.0 on the Richter scale which has the potential to cause a tsunami [16]. To deal with the possibility of a tsunami, the government of Banda Aceh City should prepare a system that enables disaster victims to access clean water. This is part of disaster mitigation which if performed well, it can help to improve access to clean water in post-disaster period.

The Regulation of the Head of Indonesian National Board for Disaster Management Number 4 of 2008 concerning the Guidelines for Preparing Disaster Management Plans states that the government can carry out disaster management planning in the form of disaster preparedness carried out by the Regional Disaster Management Agency in coordination with various agencies in pre-disaster, during disaster, and postdisaster period. The Indonesian National Board for Disaster Management has also issued the Guidelines regarding Clean Water, Sanitation and Hygiene Assistance in Disaster Emergencies as the basis or reference for cross-sector related disaster management processes in meeting the needs of clean water for disaster victims.

Based on the data collected by the researchers through reading the constitutions, the mayor regulations, research journals, and having discussions with the research supervisors, government agencies that are responsible for improving access to clean water in Banda Aceh City were the Regional Drinking Water Company of Tirta Daroy of Banda Aceh City, the Department of Public Works and Spatial Planning of Banda Aceh City, the Development Planning Agency at Sub-National Level of Banda Aceh City, and the Public Health Office of Banda Aceh City, and the Regional Disaster Management Agency of Banda Aceh City.

Moreover, the Regional Drinking Water Company of Tirta Daroy of Banda Aceh City, the Department of Public Works and Spatial Planning of Banda Aceh City, and the Development Planning Agency at Sub-National Level of Banda Aceh City coordinate the work of the procurement and management of clean water infrastructures in Banda Aceh City. The Regional Disaster Management Agency of Banda Aceh City is responsible for coordinating the implementation of disaster management activities with other institutions related human resources and logistics. On the other hand, the Public Health Office of Banda Aceh City is responsible for maintaining the quality of clean water in Banda Aceh.

In conclusion, each institution has its own role. This is what is important in this study, to ask several questions, namely: How is the synergy between government agencies in preparing clean water for earthquake and tsunami disaster management in Banda Aceh City? clean water for earthquake and tsunami disaster management in Banda Aceh City?, and How to create a model of synergy between government agencies in disaster management efforts, one of which is the logistics of clean water supply in Banda Aceh City?. So that this study can describe in more detail how the synergy between the government agencies to improve access to clean water in relation to earthquake and tsunami disaster management in Banda Aceh City.

\section{Research Method}

This study used qualitative approach. The researchers collected data through interview, observation, and literature review. The interview was conducted with five government agencies responsible for improving access to clean water in Banda Aceh City that were the head of the Sub-Division of Public Works, Spatial Planning and Defense of the Development Planning Agency at SubNational Level of Banda Aceh City, the head of the Emergency and Logistics Division of the Regional 
Disaster Management Agency of Banda Aceh City, the head of the Environmental Sanitation and Water Supply Division of the Department of Public Works and Spatial Planning of Banda Aceh City, the head of Planning and Technical Development of the Regional Drinking Water Company of Tirta Daroy of Banda Aceh City, and the executor of the Food and Beverage Processing Site Program of the Public Health Office of Banda Aceh City.

The researchers conducted an observation at the government agencies that were responsible for improving access to clean water. The researchers observed how the Regional Drinking Water Company of Tirta Daroy of Banda Aceh City processed, produced, and distributed clean water. The researchers also visited the logistics warehouse of the Regional Disaster Management Agency of Banda Aceh City. The researchers collected data from research journals, books, magazines published by the government agencies, the constitutions, and other supporting documents related to clean water supply.

After collecting data, the researcher conducted data reduction that was the activities of simplying, classifying, and discarding unrelevant data. The data was classified into 3 categories that were the roles of each government agency, the synergy pattern between the government agencies, the factors that affected the synergy between the government agencies. The criteria to describe the supporting and inhibiting factors were communication, awareness of the importance of coordination, participant competence, agreement, commitment, incentives, continuity of planning [17], evaluation [18], work division [19], responsibility, mutual contribution, and effort [20].

The next stage was that the researchers presented the data about the roles of each government agency, the synergy pattern between the government agencies, the factors that affected the synergy between the government agencies. The researchers also created a synergy model between the government agencies to improve access to clean water. The final stage was that the researchers drew a conclusion of how the synergy between the government agencies to improve access to clean water, the synergy pattern between the government agencies, and the factors that affected the synergy between the government agencies. The researchers created a synergy model between the government agencies to improve access to clean water based on logistics management system and disaster management equipment from the National Disaster Management Agency.

\section{Results and discussion}

\subsection{The government agencies as executors of the policy on improving access to clean water}

Based on the collected data, not all of the responsible government agencies executed the policy on improving access to clean water. The Development Planning Agency at Sub-National Level of Banda Aceh City, the Department of Public Works and Spatial Planning of
Banda Aceh City, and the Regional Drinking Water Company of Tirta Daroy of Banda Aceh City were the government agencies as executors of the policy on improving access to clean water. On the other hand, the Regional Disaster Management Agency of Banda Aceh City and the Public Health Office of Banda Aceh City were related agencies, but they did not take part as executors of the policy on improving access to clean water. This is illustrated in the figure 1 .

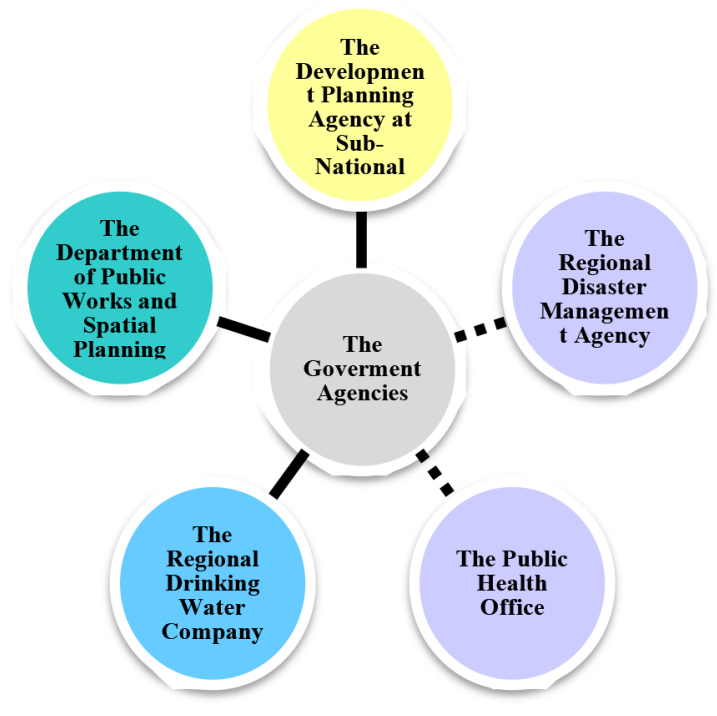

The Responsible Agencies Involved
The Responsible Agencies Not Involved

Fig. 1. The government agencies as executors of the policy on improving access to clean water.

\subsection{The synergy between the executors}

Based on the collected data, here are the roles of each executor. The Development Planning Agency at SubNational Level of Banda Aceh City played a role in funding and budgeting for the project, the Department of Public Works and Spatial Planning of Banda Aceh City played a role in building the Drinking Water Supply System, and the Regional Drinking Water Company of Tirta Daroy of Banda Aceh City played a role in managing the clean water supply in Banda Aceh City. This synergy is illustrated in the figure 2 .

The Public Health Office of Banda Aceh City played a role in monitoring the quality of clean water. The Public Health Office of Banda Aceh City did not inform the results of the work to the Regional Drinking Water Company of Tirta Daroy of Banda Aceh City. On the other hand, the Regional Drinking Water Company of Tirta Daroy of Banda Aceh City was the agency responsible for managing clean water supply in Banda Aceh City. The Public Health Office of Banda Aceh City should have submitted the report on monitoring the quality of clean water. 


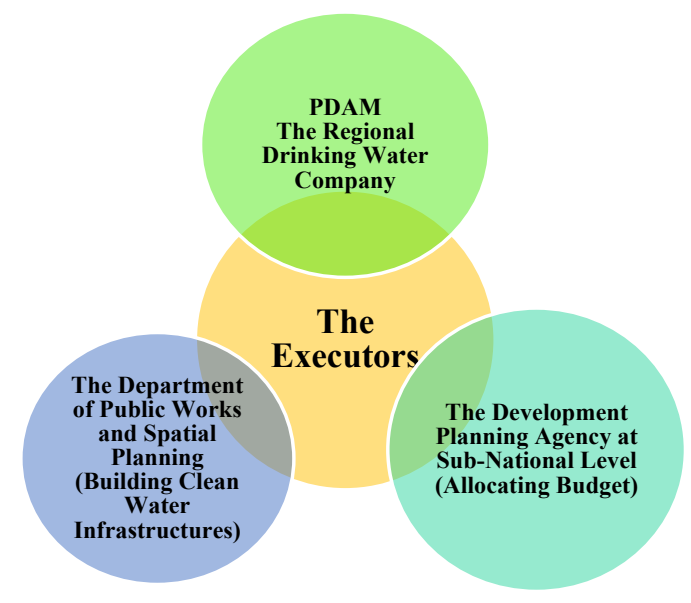

Fig. 2. The synergy between the executors.

The Public Health Office of Banda Aceh City carried out its duty by only involving the Community Health Center in each sub-district in Banda Aceh City. The report on monitoring the quality of clean water published on the Health Profile Book of Banda Aceh City and was not submitted to the Regional Drinking Water Company of Tirta Daroy of Banda Aceh City. The Regional Disaster Management Agency of Banda Aceh City responsible for coordinating the implementation of disaster management activities with other institutions had not yet carried out integrated disaster management because in the strategic plan of the Regional Disaster Management Agency of Banda Aceh City for 2018-2020 there was no clean water plan in earthquake and tsunami disaster management.

\subsection{Factors affecting the synergy between the government agencies}

\subsubsection{The supporting factors}

These supporting factors were concluded based on the analysis of the criteria mentioned above. In the aspect of communication, the Development Planning Agency at Sub-National Level of Banda Aceh City, the Department of Public Works and Spatial Planning of Banda Aceh City, and the Regional Drinking Water Company of Tirta Daroy of Banda Aceh City established an effective communication. For example, the Development Planning Agency at Sub-National Level of Banda Aceh City held a development plan meeting with the Regional Work Units of Banda Aceh City.

The results of the meeting became the guidelines for the Development Planning Agency at Sub-National Level of Banda Aceh City in carrying out its duties one of which was the construction of Drinking Water Supply System buildings. This is in accordance with what is stated by (Hasibuan \& Hasibuan, 2016) that in communication science there is a systematic effort to firmly formulate the principles, and on these principles information is conveyed in the form of opinions and attitudes.
In the aspect of awareness of the importance of coordination, the Development Planning Agency at Sub-National Level of Banda Aceh City, the Department of Public Works and Spatial Planning of Banda Aceh City, and the Regional Drinking Water Company of Tirta Daroy of Banda Aceh City had awareness of the importance of coordination. This is concluded based on the interview with the head of the three institutions.

Each institution stated the importance of coordination, especially in the construction of Drinking Water Supply System buildings in Banda Aceh City. This is in accordance with the opinion expressed by Hasibuan and Hasibuan (2016) regarding the factors that affect coordination that are the awareness of each institution with other institutions to adjust theirselves to one another or their duties with other institutions so that these institutions do not work independently.

In the aspect of participant competency, each agency involved people who were competent in the construction of Drinking Water Supply System buildings. In the aspect of agreement, commitment, and incentives, the Development Planning Agency at Sub-National Level of Banda Aceh City, the Department of Public Works and Spatial Planning of Banda Aceh City, and the Regional Drinking Water Company of Tirta Daroy of Banda Aceh City kept to the agreement and showed a commitment. Also, everyone involved in the construction of Drinking Water Supply System buildings got incentives.

\subsubsection{The inhibiting factors}

These inhibiting factors were concluded based on the analysis of the criteria mentioned above. In the aspect of continuity planning, the program was not well planned because the progeam was based on a proposal from the Regional Drinking Water Company of Tirta Daroy of Banda Aceh City which was accommodated by the Department of Public Works and Spatial Planning of Banda Aceh City which then the proposal was submited to the Development Planning Agency at Sub-National Level of Banda Aceh City. The Department of Public Works and Spatial Planning of Banda Aceh City was the one who responsible to do the planning and assessment of the construction of Drinking Water Supply System buildings, and The Department of Public Works and Spatial Planning of Banda Aceh City should not only accept the proposal from the Regional Drinking Water Company of Banda Aceh City.

The Department of Public Works and Spatial Planning should do checking in the field to ensure that the proposal of the Regional Drinking Water Company of Tirta Daroy was suitable or not. In the aspect of work division, it was unclear due to the overlapping tasks between the Department of Public Works and Spatial Planning of Banda Aceh City and the Regional Drinking Water Company of Tirta Daroy of Banda Aceh City regarding the pipeline network planning of the Regional Drinking Water Company.

The Department of Public Works and Spatial Planning of Banda Aceh City was the one who should 
carry out the planning of the construction of the Drinking Water Supply System buildings. However, the task was carried out by the Regional Drinking Water Company of Tirta Daroy with a Detail Engineering Design (DED). So, it is clear that the Department of Public Works and Spatial Planning of Banda Aceh City did not carry out their duties properly.

In the aspect of evaluation, there was no evaluation of the agreement. Evaluation is very important to form an opinion of the quality of the program. From the evaluation, it can be seen which programs have been carried out and which programs have not been completed. This conclusion was obtained based on the interview in the field. The Department of Public Works and Spatial Planning of Banda Aceh City, the executor of the construction of the Drinking Water Supply System buildings, did not have the data such as how long the pipes had been built. In fact, this is the basic data as the guidelines for the next Drinking Water Supply System development. It can be concluded that the Department of Public Works and Spatial Planning of Banda Aceh City did not evaluate its work.

This indicated that the data on the construction of the Drinking Water Supply System buildings was unclear which then caused unclear construction planning of Drinking Water Supply System building in Banda Aceh City. The construction of Drinking Water Supply System buildings usually ruined the other infrastructures such as roads. Such problem occurred because the Department of Public Works and Spatial Planning of Banda Aceh City, the executor of the construction of Drinking Water Supply System buildings, did not have valid data on the construction of Drinking Water Supply System buildings. The Department of Public Works and
Spatial Planning of Banda Aceh City also built roads, bridges, drainage, and irrigation which were not synchronous between each sector. This can be concluded that in the field there was often damage to pipelines on the basis of other infrastructure development.

The inhibiting factors described above are in accordance with what is stated by Soewarno (2006) that the unclear formulation of duties, authorities, and responsibilities of each institution, the work procedure are not understood by the parties who sometimes raise doubts between them.

\subsection{The synergy model of clean water access improvement}

To realize the synergy between the government agencies to improve access to clean water in Banda Aceh City, it is necessary to create a synergy model so that the Development Planning Agency at Sub-National Level of Banda Aceh City, the Department of Public Works and Spatial Planning of Banda Aceh City, the Regional Drinking Water Company of Tirta Daroy of Banda Aceh City, the Regional Disaster Management Agency of Banda Aceh City, and the Public Health Office of Banda Aceh City can be together and involved in clean water access improvement.

This synergy model was created based on several findings in the field and based on the supporting and inhibiting factors affecting the synergy of the government agencies.

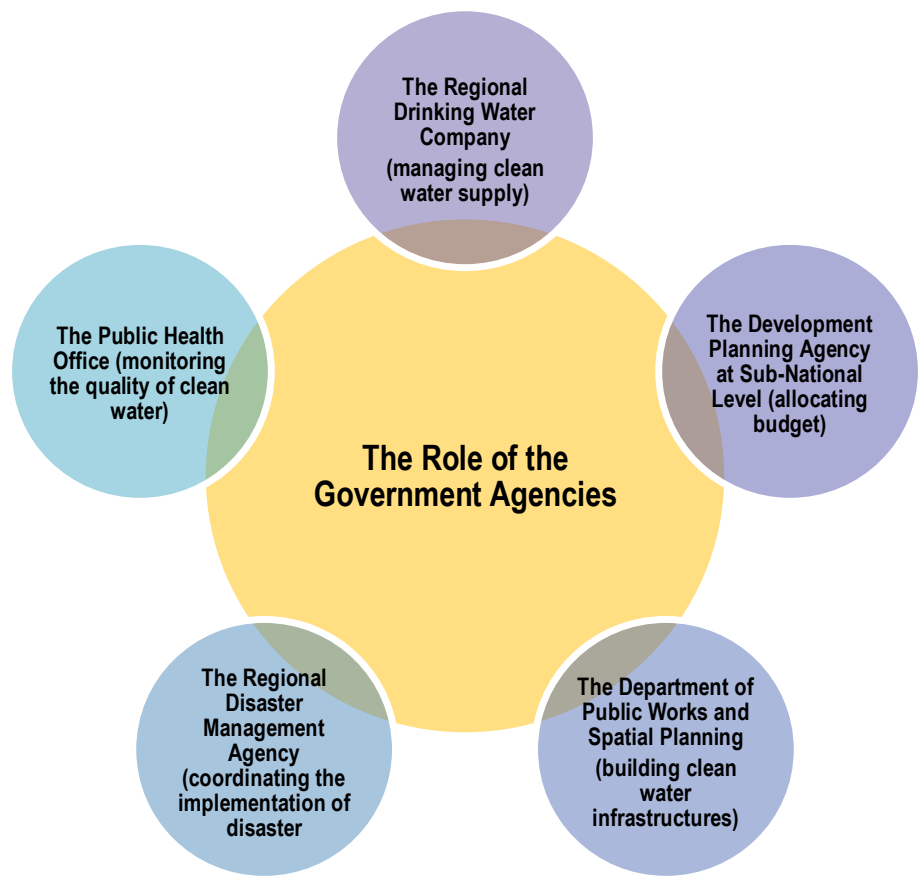

Improving Access To Clean Water

Fig. 3. The synergy model of clean water access improvement 

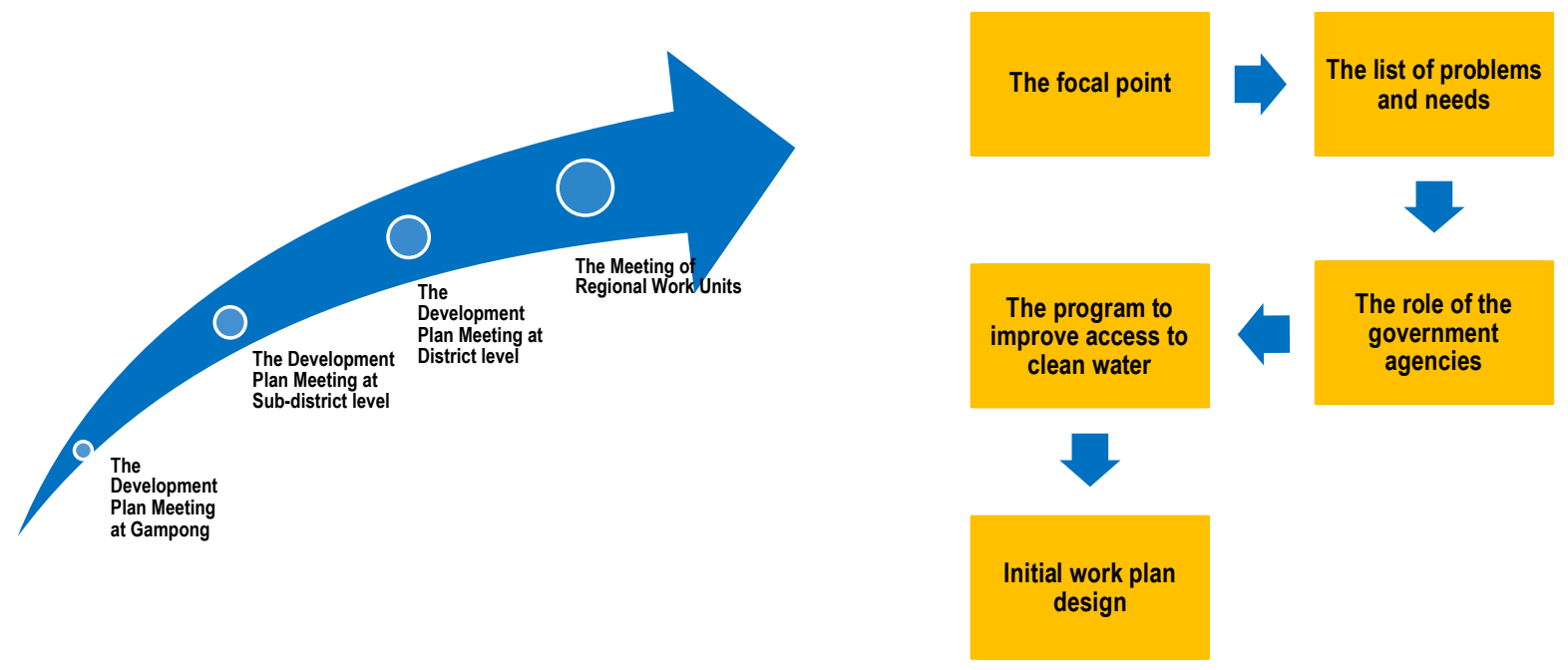

Fig. 4. Clean water access improvement planning into the regional medium term development plan

The focal point is the Regional Disaster Management Agency of Banda Aceh City, the agency responsible for disaster management. The Regional Disaster Management Agency of Banda Aceh City should coordinate the program of improving access to clean water with other agencies. The Regional Disaster Management Agency of Banda Aceh City must be the one who designs the policy, and it also must be more active in carrying out its duties. The Regional Disaster Management Agency of Banda Aceh City must conduct meetings with the Department of Public Works and Spatial Planning of Banda Aceh City, the Regional Drinking Water Company of Tirta Daroy of Banda Aceh City, and the Public Health Office of Banda Aceh City. The data obtained from the meetings should be written on a document that lists problems and needs related to the program of improving access to clean water.

The list of problems and needs will provide information on the potential number of disaster victims, how many liters of clean water is needed, how many water storage tanks are needed. After an earthquake and tsunami, the building of Drinking Water Supply System is ruined, so raw water cannot be processed into clean water. As a result, it is necessary to provide cars to distribute clean water and equipment to distill water.

Each agency has its role in improving access to clean water. The Regional Disaster Management Agency of Banda Aceh City has a role to assess the number of disaster victims, how much clean water is needed, how many water storage tanks are needed, how many water tank cars are needed, and how many distillers are needed. The Department of Public Works and Spatial Planning of Banda Aceh City has a role to provide needs from the data of the Regional Disaster Management Agency of Banda Aceh City and repair the building of of Drinking Water Supply System. The Regional Drinking Water Company of Tirta Daroy of Banda Aceh City has a role to ensure the availability of water in water storage tanks and equipment for distilling water, distribute water, and ensure that the clean water supply is enough. The Public Health Office of Banda Aceh City has a role to monitor water quality.

\section{Conclusion}

Not all agencies related to clean water access improvement are involved in implementing the policy. Therefore, it is necessary to create a synergy model between government agencies in clean water access improvement, and the synergy model is included in the Disaster Management Plan implemented by the Regional Disaster Management Agency of Banda Aceh City together with the Department of Public Works and Spatial Planning of Banda Aceh City, the Regional Drinking Water Company of Tirta Daroy of Banda Aceh City, and the Public Health Office of Banda Aceh City. Furthermore, the Disaster Management Plan is included in the Strategic Plan of each government agency involved. Furthermore, the Disaster Management Plan is recommended to the Development Planning Agency at Sub-National Level of Banda Aceh City to be included in the Regional Medium Term Development Plan.

\section{References}

1. BNPB, Kepala Pus. Data Inf. Dan Humas BNPB (2018)

2. H. A. Eiselt and V. Marianov, Eur. J. Oper. Res. 216, 563 (2012)

3. L. McReynolds and R. L. Simmons, JournalAmerican Water Work. Assoc. 87, 65 (1995)

4. C. R. Scawthorn, Earthq. Spectra 27, 419 (2011)

5. A. R. Hidayat, R. Triatmadja, and I. Supraba, IOP Conf. Ser. Earth Environ. Sci. 426, (2020)

6. B. P. Wham, S. Dashti, K. Franke, R. Kayen, and N. K. Oettle, Lowl. Technol. Int. 19, 151 (2017)

7. T. W. Ignasius D.A. Sutapa, LIMNOTEK Perair. Darat Trop. Di Indones. 21, 135 (2014) 
8. J. Song, M. Han, T. Kim, and J. Song, Desalination 248, 233 (2009)

9. A. Rahman, S. Iwasaki, S. A. Sutton, A. Sakurai, and Parmakope, Urban Water Management Issues and Challenges After the 2004 Indian Ocean Tsunami Recovery: Lessons Learned from Banda Aceh City, Indonesia (Springer Singapore, 2019)

10. A. Ganas, V. Tsironi, and S. Valkaniotis, (2018)

11. Y. Darma, B. Sulistyantara, and Yonvitner, IOP Conf. Ser. Earth Environ. Sci. 501, (2020)

12. T. Anasiru, S. Tahir, and Anawardiayah, Siimo Eng. 4, 1 (2020)

13. M. S. Yadnya, A. Tahmid, A. Zainuddin, B. Kanata, T. Zubaidah, and P. Paniran, J. Gema Ngabdi 2, 63 (2020)

14. Gusmeri, Fadhil, and R. S. Oktari, Strategi Mitigasi Bencana Tsunami Dan Banjir Rob Yang Diperparah Oleh Kenaikan Muka Air Laut Akibat Perubahan Iklim Di Kota Banda Aceh (2019)

15. D. H. Natawidjaja, J. Ris. Geol. Dan Pertamb. 25, 49 (2015)

16. I. Rusydy, U. Muksin, Mulkal, Y. Idris, M. N. Akram, and Syamsidik, in AIP Conf. Proc. (AIP Publishing LLC, 2018), p. 20012

17. H. Soewarno, Penerbit PT. Toko Gunung Agung, Jakarta (2006)

18. Manullang, Dasar - Dasar Manajemen (Ghalia Indonesia, Yogyakarta, 2008)

19. M. S. P. Hasibuan and H. M. S. P. Hasibuan, Manajemen Sumber Daya Manusia (Bumi Aksara, 2016)

20. M. West, Cetakan Kelima. Penerjemah: Srikandi Waluyo. Yogyakarta: Penerbit Kanisius (2002) 